\title{
20. SECONDARY MINERAL ASSEMBLAGES IN A VOLCANIC SEQUENCE DRILLED DURING ODP LEG 104 IN THE NORWEGIAN SEA ${ }^{1}$
}

\author{
A. Desprairies, P. Tremblay, and C. Laloy ${ }^{2}$
}

\begin{abstract}
Mineralogical and geochemical analyses of alteration products from upper and lower volcanic series recovered during ODP Leg 104 reveal variations both in composition and order of crystallization of clay minerals vesicles and voids filling and replacing glass. These results provide information about successive alteration stages of rocks and interlayered volcaniclastic sediments. The first stage, related to initial basalt-seawater interaction, is characterized by development of Fe-smectites, especially Fe-rich saponite. A second stage of intermittently superimposed subaerial weathering is marked by iron-oxides-halloysite-kaolinite formation. The third episode, interpreted as hydrothermal on the basis of $\mathrm{O}-$ isotopic data, is defined by postburial coprecipitation of Fe-poor, $\mathrm{Mg}$-rich saponite and celadonite. A distinct final and pervasive hydrothermal stage, occurring mainly in the lower series and dominated by Al-smectites-zeolites assemblage, indicates changes toward a more reducing alteration environment.
\end{abstract}

\section{INTRODUCTION}

The main objective of Leg 104 was to determine the composition and nature of a dipping-reflector sequence and its underlying rock by drilling the Vøring Plateau off northern Norway. At Site $642\left(67^{\circ} 13.5^{\prime} \mathrm{N}, 02^{\circ} 55.8^{\prime} \mathrm{E}\right)$ (Fig. 1), a 914-m-thick Eocene section of lavas and intercalated volcaniclastic sediments was recovered below a 315 -m-thick cover of predominantly pelagic and hemipelagic upper Cenozoic sediments (Eldholm, Thiede, Taylor, et al., 1987). The volcanic sequence can be divided into an upper and lower series based on textural, mineralogical, and structural characteristics of the flows as well as on the composition of interlayered volcaniclastic sediments. The 773-m-thick upper series consists of 122 tholeiitic basaltic flows. The interlayered volcaniclastic sediments (tuffs) which make up about $4 \%$ of the series are mostly basaltic-vitric in composition.

Two varieties of flow, fine and medium grained, which differ in quantitative mineral content, granularity, internal flow fabric, and average thickness were observed. Fine-grained flows have an average thickness of $8 \mathrm{~m}$. These flows are characterized by a well-preserved zonal structure consisting, throughout an idealized section, of

1. A brecciated, scoriaceous, highly vesicular flow top (average $0.75 \mathrm{~m}$ ).

2. An upper vesicular zone $(2.50 \mathrm{~m})$. Vesicles have an average diameter of $2 \mathrm{~mm}$ and a maximum diameter up to $1 \mathrm{~cm}$. The number of vesicles decreases gradually with depth, although their average size remains constant.

3. A central streaked zone $(4 \mathrm{~m})$ identified by occurrence of spaced, laminar, subhorizontal to randomly oriented, foliation. Vesicles are rare or absent.

4. A lower vesicular zone $(0.5 \mathrm{~m})$ characterized by increasing vesicularity towards the base of flow.

5. A basal breccia $(0.25 \mathrm{~m})$ rarely recovered.

Medium-grained flows have an average thickness of $3 \mathrm{~m}$. They differ markedly from the fine-grained flows by the lack of

\footnotetext{
${ }^{1}$ Eldholm, O., Thiede, J., Taylor, E., et al., 1989. Proc. ODP, Sci. Results, 104: College Station, TX (Ocean Drilling Program).

2 Université de Paris-Sud, Laboratoire de Géochimie des Roches Sédimentaires, Bátiment 504, 91405 Orsay Cedex, France.
}

the central streaked zone. The lithological differences between flow types are not reflected chemically; however, the relative proportion of the fine and medium-grained flows permits a subdivision of the upper series into three groups (Fig. 2). The presence of reddened scoriaceous tops to some flows without pillow structures or thick glassy crusts and of dark-brown tuffs suggest subaerial and/or shallow marine conditions of emplacement. The dipping-reflector sequence is related entirely to the cyclic alternation of flows and sediments.

The lower volcanic series, $136 \mathrm{~m}$ thick, is separated from the upper volcanic series by a 5 -m-thick eutaxitic tuff ( $\mathrm{K}$ reflector). It consists of $43 \%$ flows, $21 \%$ volcaniclastic sediments, and $36 \%$ dikes (Fig. 2). Sixteen flows and four dike-units, ranging from basaltic to peraluminous andesitic composition, were identified in the lower series. Flow textures are glassy and partly hydrated to perlites, variolitic, or microcrystalline. Volcaniclastic sediments in the lower series are dissimilar to those in the upper series. They contain terrigenous components and glass shards are mostly rhyo-dacitic in composition. Volcaniclastic sediments include a 7-m-thick ashflow interpreted as subaqueously deposited ignimbrite. Preliminary geochemical data (Eldholm, Thiede, Taylor, et al., 1987) suggest a continental rift environment during the eruption of the lower series with a later change to more Icelandic type for the upper series.

Several types of secondary alteration assemblages were distinguished through shipboard macro- and microscopic observations and some XRD analyses. In the upper series, reddening of flow tops, brecciated zones, and tuffs occur intermittently (Fig. 2) throughout the entire tholeiitic pile and are interpreted as being due to oxidation during subaerial eruption. All primary minerals and groundmass are replaced by clay minerals (kaolinite, geothite) coated with goethite/hematite. Another type of alteration affects all volcanics of the upper series and consists of a smectite-celadonite assemblage. The secondary minerals fill the vesicles, interstices, and fractures of the medium- and finegrained flows, reddened or not, and develop partly through volcaniclastic sediments. Vesicles are often zoned with the typical sequence, from rim to core, of smectites (saponite), celadonite, calcite and, rarely, zeolites. A distinctive alteration assemblage first appears about $40 \mathrm{~m}$ above the base of the upper series. This alteration stage is characterized by bleached discoloration and orange-red iron staining around vesicles, fractures, and phenocrysts. The bleached zones contain locally siderite and quartz. The effects of this event, possibly related to higher tem- 


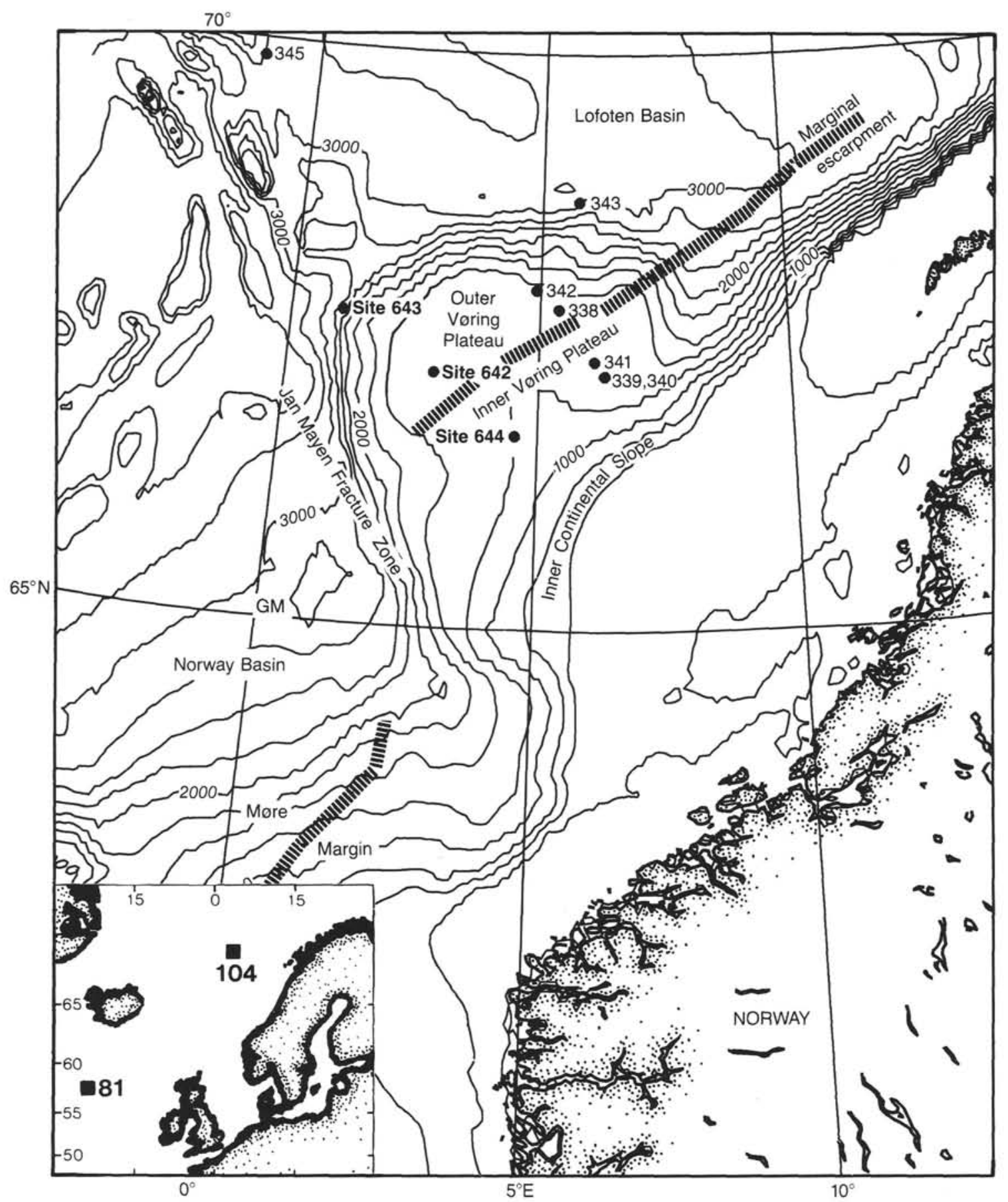

Figure 1. Location map of the Vøring Plateau showing the ODP Leg $104(642,643,644)$ drilling sites. Contour interval $250 \mathrm{~m}$. Inset: Location of DSDP Leg 81 at the southwest margin of the Rockall Plateau, with respect to ODP Leg 104.

perature fluids, are pervasive in the lower series, resulting in white to light-gray coloration of glasses. Vesicles exhibit zonation from smectite rims to a variety of zeolites, mordenite and chabazite being the most common, and finally calcite and/or quartz in the core.

This paper presents data on Hole 642E volcanic secondary minerals with the aim of determining their paragenesis, and recognizes a sequence of various alteration stages. We also add unpublished data on the volcanic sequence drilled during DSDP Leg 81, Rockall Plateau (Roberts, Schnitker, et al., 1984), ex- truded in an environment analogous to that of the Leg 104 basalts and which show similar alteration processes.

\section{ANALYTICAL PROCEDURE}

X-ray mineralogy was conducted on 103 samples obtained by scraping infilled vesicles and veins and altered groundmass from volcanic flows and volcaniclastic sediments (Fig. 2). Data were recorded for both powder and oriented specimens.

A scanning electron microscope (SEM, Philips 505) fitted with an X-ray dispersive spectrometer (LINK AN 10000, Si-Li 


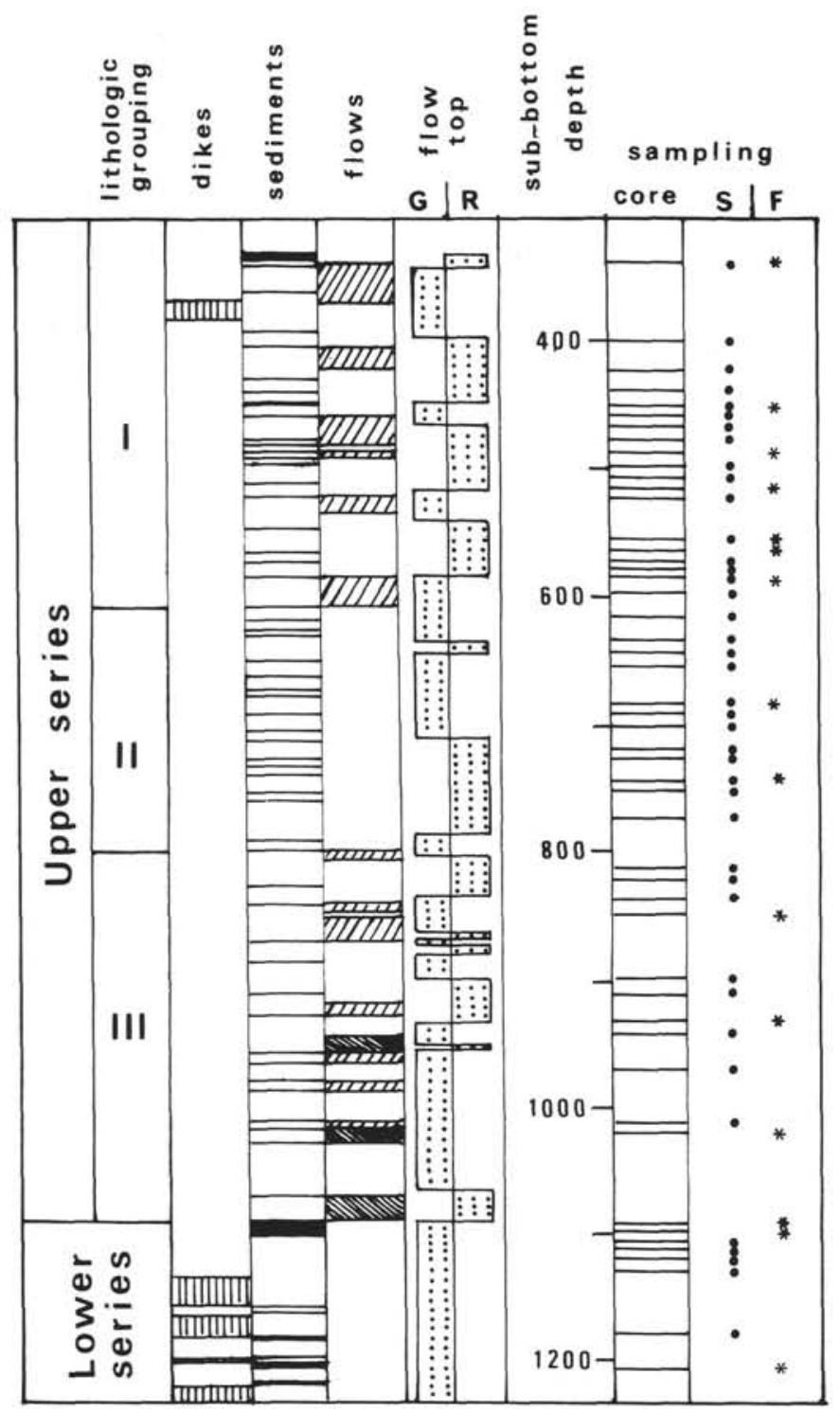

Figure 2. Lithostratigraphy and sampling of the volcanic sequence, Site 642. Flows: no ornament $=$ fine-grained flows, right-slant hatching $=$ medium-grained flows, left-slant hatching $=$ mixed flows. Flow top: $\mathrm{G}=$ gray, $\mathrm{R}=$ reddened (reprinted from Eldholm, Thiede, Taylor, et al., 1987). Samples: Filled circles and stars indicate the samples taken from flow (F) and sediment (S) cores.

detector) was used for morphological examination, point mineral analysis, and global analyses of samples over several square millimeters. Quantitative analyses were conducted with ZAF (Z absorption fluorescence) programs (ZAF 4/FLS and ZAF PB/ FLS provided by LINK Analytical), on polished surfaces or on pellets of crushed and pressed powder. The relative errors were less than $3 \%$ for elements whose concentrations were greater than $10 \%, 5 \%$ for element concentrations between 5 and $10 \%$, and $20 \%$ for elemental concentration $<5 \%$. The detection limit for all elements was $0.1 \%$. Totals obtained average $85 \% \pm$ 5 for clay minerals. Results were normalized to 100 percentage (oxide values by weight, water free basis) to allow for comparison. For some clay minerals specimens, SEM results were confirmed by atomic absorption spectrometry analyses and the $\mathrm{Fe}^{2+} / \mathrm{Fe}^{3+}$ ratio determined by oxidation-reduction titration.
Elemental mapping was performed with programs DIGIMAP (ADM.SV and DIGIPAD.SV) provided by LINK Analytical. Background corrections were made by substraction of a background window near the element window. Image brightnesses presented in this paper are proportional to the apparent concentrations of elements. Samples for clay mineral isotopic analyses were first checked for mineralogic homogeneity by $\mathrm{X}$ ray diffraction. Subsequently, conventional techniques were used for extracting oxygen with bromide pentafluoride, followed by $\mathrm{O}_{2}$ conversion to carbon dioxide (Clayton and Mayeda, 1963). Isotope ratios were reported in parts per mil relative to standard mean ocean water (SMOW) and temperatures were estimated using fractionation factors from Savin and Epstein (1970) and Escande (1983).

\section{RESULTS}

\section{X-ray Diffraction Study}

Minerals associated with phyllosilicates-quartz, alkali feldspars, plagioclases, zeolites, goethite, and hematite-were recognized using powder diffraction data and values of diagnostic reflections. Kaolinite and halloysite, identified by classical treatments (heating, hydrazine complex; Brindley and Brown, 1980), were found only in paleosoils developed on vitric tuffs of the upper series and in volcaniclastic sediments interbedded between the two series (reflector K). We describe here only the Xray identification procedure for clay minerals clearly related to submarine weathering.

Two diffractometer methods were used. Suspension-sedimented samples provided oriented clay specimens showing only the 001 series of basal reflection. Various treatments (ethylene-glycol or glycerol, heating, saturation with different exchangeable cations) were applied to clay slides, and the changes of basal spacing were associated with the layer charge value in smectite phases. Diffraction patterns from randomly oriented samples, ground to powder, enabled the recognition of di-and trioctahedral forms, based on hkl reflections and measurement of the $d(060)$ spacing value.

\section{Celadonite Species}

$\mathrm{X}$-ray powder data for celadonite are those of the $1 \mathrm{M}$ form. The value of the b-parameter, between 9.048 and $9.066 \AA$ (Tables 1 and 2), reveals an iron-rich dioctahedral structure. The celadonite crystallinity is high and, by application of the Scherrer equation (in Brindley and Brown, 1980), the averaged thickness of crystallites is about $300 \AA$ or 30 layers, and values obtained for the mean diameter of lattice coherence in the $(a, b)$ plane of the layers range from about 300 - to $350 \AA$. On oriented slides, the $\mathrm{d}(001)$ spacing value, near $10 \AA(10.06 \AA-10.14 \AA)$, does not change after various treatments as is usual for clay minerals from the true mica group.

\section{Smectite Species}

On randomly-oriented samples, distinction between dioctahedral and trioctahedral smectites can be made using the values of nonbasal diffractions and particularly those of $(06,33)$ bands. The two subgroups were recognized and their identification confirmed by chemical analyses both in volcaniclastic sediments and altered lavas of the upper and lower units.

\section{Beidellite-nontronite Series}

Measurements of the $b$ parameter, ranging from $9.00 \AA$ to $9.04 \AA$, are distinctive of a beidellite-iron-beidellite suite in which all intermediate compositions were found (Tables 2 and $3)$. However, we have never observed the d (060) of nontronite 
Table 1. Chemical analyses, structural formulas, and $b$-parameter of celadonite (sample A) and saponites (samples 1 to 10) from volcanic flows of the upper series, Hole 642E. Color: blue-green (A), light-green (1, 3 to 6 ), dark-green ( 2,8 to 10 ), black (7). $X, Y, Z$ are the values of the tetrahedral, octahedral, and interlayer charges, respectively. The $b$-parameters are estimated from the " 060 " reflections and related to the peak intensities $(w=$ weak, $\mathbf{m}=$ medium).

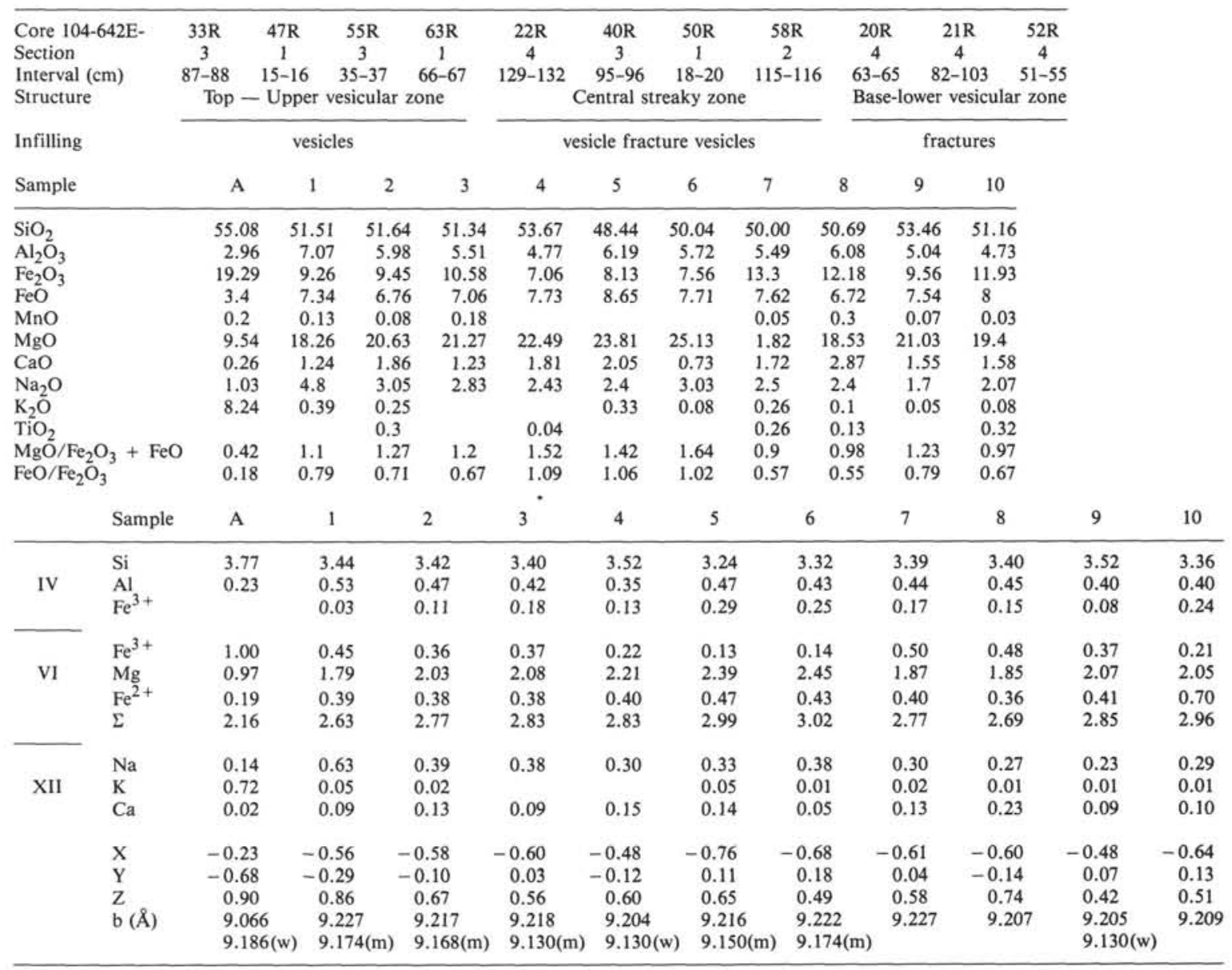

end-member of this series. Other X-ray powder data on these smectites indicate a low average crystallite thickness of the order of $70 \AA$ to $130 \AA$ and a mean diameter in the $(a, b)$ plane in the range of $120 \AA$ to $240 \AA$. A correlation is obvious between the increasing iron content of beidellites and the decreasing size of the mean diameter. On oriented slides, the $\mathrm{d}(001)$ basal spacing is about $12.5 \AA$, resulting from one layer of water. The behavior following heating (collapse to $10 \AA$ ) and saturation with ethylene-glycol (swelling to $16 \AA-17 \AA$ ) is characteristic of expanding minerals having a low layer charge.

\section{$\mathrm{Mg}$-Fe Saponite Series}

The X-ray powder pattern of trioctahedral smectites exhibits either a single $(06,33)$ diffraction band at $1.538 \AA-1.535 \AA$ or a doublet at $1.536 \AA-1.534 \AA$ and $1.529 \AA-1.520 \AA$ (Tables 1-3). Measurements utilizing the Scherrer equation indicate smaller size crystallites packets in the $(a, b)$ plane for specimens showing a $b$-parameter of $9.20 \AA(140 \AA-200 \AA)$ than for those showing a $b$-parameter of $9.12 \AA-9.17 \AA(210 \AA-270 \AA)$.

On oriented slides, the responses to treatment of trioctahedral smectites can be quite different. Our observations indicate two characteristic changes:

1. In their normal, room-temperature, hydration state, some samples present a sharp basal spacing near $12 \AA(12.2 \AA-12.7$
$\AA$ ) corresponding approximately to a thickness of 12 to 14 layers; this reflection, after heating, contracts to $9.5 \AA-9.7 \AA$ and expands to $16.7 \AA-16.9 \AA$ with ethylene-glycol. In this latter case (002) and (003), successive orders are well recorded. These samples always show a single value of $b$-parameter $(9.20 \AA-9.23$ $\AA)$.

2. X-ray patterns showing two distinct values of $b$-parameter, as already mentioned, are characteristic of these samples. A broad basal spacing shifts toward $10 \AA-11 \AA$ (11.6 $\AA$ to $10.3 \AA)$ or splits into two reflections near $12 \AA$ and $10 \AA-11 \AA$. With ethylene-glycol one part forms a one-layer complex at $13 \AA-$ $13.6 \AA$ and the other part gives two-layer complexes at $16.6 \AA-$ $16.8 \AA$ as in the previous samples. Heating at $500^{\circ} \mathrm{C}$ first produces a total contraction to $9.6 \AA$ but, in moist air, rehydration partially occurs and a $12-\AA$ phase appears close to the remaining $9.6-\AA$ phase.

In summary the $b$-parameter values and the effects of various treatments on basal spacings indicate that two species of trioctahedral smectites are present alone or associated. With treatment we have never observed a progressive displacement of reflections suggesting steps of interstratification. Some specimens react as normal low-charge saponites (two layers of ethyleneglycol complexes, irreversible collapse after heating). Others, characterized by 0 to 1 water layer, one layer of ethylene-glycol, 
Table 2. Chemical analyses, structural formulas, and $b$-parameter of clay minerals from altered volcaniclastic sediments of the upper series, Hole 642E. Samples 1, 2: Beidellite and iron-beidellite from the dark-gray groundmass of basaltic clasts. Samples 3, 4, 5: From rim to core of completely infilled vug or vesicle, brown mixture of saponite and beidellite (3), blue-green celadonite (4) and green saponite (5). Sample 6: Iron-beidellite from entirely argillized glasses in darkbrown vitric tuff. Sample 7: Cement of gray saponite in red-brown vitric tuff. Total iron is expressed as $\mathrm{Fe}_{2} \mathrm{O}_{3}$. b: See Table 1 .

\begin{tabular}{|c|c|c|c|c|c|c|c|c|c|c|}
\hline \multicolumn{2}{|c|}{$\begin{array}{l}\text { Core 104-642E- } \\
\text { Section } \\
\text { Interval }(\mathrm{cm}) \\
\text { Structure breccia }\end{array}$} & ed-cong & $\begin{array}{l}19 \mathrm{R} \\
5 \\
23-25 \\
\text { lomeratic }\end{array}$ & c top of ves & sicular & \multirow[t]{2}{*}{ ow } & \multicolumn{2}{|c|}{$\begin{array}{cc}19 R & 85 R \\
5 & 5 \\
11-13 & 131-132 \\
\text { vitric tuffs }\end{array}$} & & \\
\hline Sample & 1 & 2 & 3 & 4 & 5 & & 7 & & & \\
\hline $\begin{array}{l}\mathrm{SiO}_{2} \\
\mathrm{Al}_{2} \mathrm{O}_{3} \\
\mathrm{Fe}_{2} \mathrm{O}_{3} \\
\mathrm{MnO} \\
\mathrm{MgO} \\
\mathrm{CaO} \\
\mathrm{Na}_{2} \mathrm{O} \\
\mathrm{K}_{2} \mathrm{O} \\
\mathrm{TiO}_{2}\end{array}$ & $\begin{array}{r}64.17 \\
19.43 \\
7.54 \\
0.05 \\
4.30 \\
2.07 \\
0.59 \\
1.23 \\
0.62\end{array}$ & $\begin{array}{r}57.56 \\
15.24 \\
13.95 \\
0.10 \\
7.72 \\
2.81 \\
0.83 \\
1.15 \\
0.64\end{array}$ & $\begin{array}{l}59.10 \\
13.28 \\
16.44 \\
\\
9.51 \\
0.41 \\
0.22 \\
0.93 \\
0.10\end{array}$ & $\begin{array}{r}58.44 \\
9.87 \\
13.07 \\
0.04 \\
7.35 \\
0.57 \\
0.44 \\
10.03 \\
0.19\end{array}$ & $\begin{array}{r}49.31 \\
8.83 \\
20.68 \\
0.09 \\
18.19 \\
0.99 \\
1.00 \\
0.79 \\
0.12\end{array}$ & $\begin{array}{r}53.87 \\
13.26 \\
20.13 \\
\\
3.73 \\
1.85 \\
2.14 \\
1.75 \\
3.26\end{array}$ & $\begin{array}{r}47.54 \\
9.32 \\
21.54 \\
0.04 \\
19.00 \\
1.55 \\
0.87 \\
0.14\end{array}$ & & & \\
\hline $\mathrm{TiO}_{2}$ & \multicolumn{2}{|c|}{ Sample } & 1 & 2 & \multicolumn{2}{|c|}{3} & 4 & 5 & 6 & 7 \\
\hline IV & \multicolumn{2}{|l|}{$\begin{array}{l}\mathrm{Si} \\
\mathrm{Al} \\
\mathrm{Fe}^{3+}\end{array}$} & $\begin{array}{l}3.90 \\
0.10\end{array}$ & $\begin{array}{l}3.65 \\
0.35\end{array}$ & \multicolumn{2}{|c|}{$\begin{array}{l}3.58 \\
0.42\end{array}$} & $\begin{array}{l}3.84 \\
0.16\end{array}$ & $\begin{array}{l}3.24 \\
0.69 \\
0.07\end{array}$ & $\begin{array}{l}3.60 \\
0.40\end{array}$ & $\begin{array}{l}3.13 \\
0.72 \\
0.15\end{array}$ \\
\hline VI & $\begin{array}{l}\mathrm{Fe}^{3+} \\
\mathrm{Al} \\
\mathrm{Mg} \\
\Sigma\end{array}$ & & $\begin{array}{l}0.34 \\
1.29 \\
0.39 \\
2.02\end{array}$ & $\begin{array}{l}0.66 \\
0.78 \\
0.73 \\
2.17\end{array}$ & & $\begin{array}{l}.75 \\
.53 \\
.86 \\
.14\end{array}$ & $\begin{array}{l}0.65 \\
0.60 \\
0.72 \\
1.97\end{array}$ & $\begin{array}{l}0.95 \\
1.78 \\
2.80\end{array}$ & $\begin{array}{l}1.01 \\
0.65 \\
0.37 \\
2.03\end{array}$ & $\begin{array}{l}0.92 \\
1.87 \\
2.79\end{array}$ \\
\hline \multirow[t]{2}{*}{ XII } & $\begin{array}{l}\mathrm{Na} \\
\mathrm{K} \\
\mathrm{Ca} \\
\mathrm{X} \\
\mathrm{Y} \\
\mathrm{Z}\end{array}$ & & $\begin{array}{l}0.06 \\
0.09 \\
0.14 \\
0.10 \\
0.33 \\
0.43\end{array}$ & $\begin{array}{r}0.10 \\
0.09 \\
0.19 \\
-0.35 \\
-0.22 \\
0.57\end{array}$ & & $\begin{array}{l}.26 \\
.07 \\
.26 \\
.42 \\
.44 \\
.85\end{array}$ & $\begin{array}{r}0.05 \\
0.84 \\
0.04 \\
-0.16 \\
-0.81 \\
0.97\end{array}$ & $\begin{array}{r}0.13 \\
0.07 \\
0.07 \\
-0.76 \\
0.41 \\
0.34\end{array}$ & $\begin{array}{r}0.27 \\
0.14 \\
0.13 \\
-0.40 \\
-0.28 \\
0.67\end{array}$ & $\begin{array}{r}0.11 \\
0.02 \\
0.11 \\
-0.87 \\
0.50 \\
0.35\end{array}$ \\
\hline & $b(\AA)$ & & 9.000 & $\begin{array}{l}9.018 \\
9.186(w)\end{array}$ & \multicolumn{2}{|c|}{$\begin{array}{l}9.020 \\
9.186(\mathrm{~m})\end{array}$} & 9.048 & 9.208 & 9.036 & 9.204 \\
\hline
\end{tabular}

and spontaneous rehydration in moist air, resemble high-charge saponite or vermiculite (Suquet et al., 1975, 1977). Chemical analyses (below) confirm this distinction.

\section{Chemical Analyses}

The intimate association of halloysite and kaolinite with iron oxides and oxyhydroxides did not permit their chemical analysis. Results and structural formulas for zeolites identified by Xray diffraction are given in Table 4 . About 100 samples of celadonite and smectites, occurring throughout the upper and lower series, were analyzed for major elements. Some of them, as shown by X-ray diffraction, are mixtures of different species or types. We present here only chemical analyses (Figs. 3 and 4, Tables 1 to 3 ) of separated monomineralic specimens.

\section{Mg-Fe Saponite Series}

Trioctahedral smectites are widely distributed within the tholeiitic flows of the upper series, replacing glass or infilling vesicles and fractures; these smectites occur to a lesser degree, in interbedded volcaniclastic sediments of the upper series and, in the lower series, they are found only as weathered pumice of one ignimbrite-flow. The main characteristic of structural formulas (Tables 1 and 2) derived from their chemical composition is a deficiency ( 0.03 to 0.29 per half unit cell) of tetrahedrally coordinated $\mathrm{Si}$ and/or $\mathrm{Al}$, resulting in a theoretical allocation of an unusual amount of $\mathrm{Fe}$ in tetrahedral position. This tetrahedral
Fe content cannot be related to low values (e.g., 75\%) of prenormalized totals and to analytical errors propagated into structural formulas. The total negative tetrahedral charge $(-0.49$ to 0.76 ) is sometimes balanced by a positive octahedral charge $($ still +0.18$)$ and, in this respect, saponite resembles vermiculite. $\mathrm{Na}$ is always the main cation in the interlayer position compensating the total negative layer charge $(-0.42$ to -0.86$)$. Based on their $\mathrm{MgO} /\left(\mathrm{Fe}_{2} \mathrm{O}_{3}+\mathrm{FeO}\right)$ ratios, and correlative color and location, two types of saponite can be distinguished:

\section{$\mathrm{Fe}$-Saponite}

Black to dark-green in color, these are defined by a $\mathrm{MgO}$ / $\left(\mathrm{Fe}_{2} \mathrm{O}_{3}+\mathrm{FeO}\right)$ ratio $<1$. The $\mathrm{X}$-ray pattern exhibits a single $(06,33)$ band at $1.534 \AA-1.538 \AA$. They occur in the altered groundmass, of flows, as complete filling of veins and fractures in the central streaky zone, as cement of green vitric tuffs and, in the lower and upper vesicular zones, form the rim of zoned vesicles. The $\mathrm{FeO} / \mathrm{Fe}_{2} \mathrm{O}_{3}$ ratios range from 0.6 to 0.7 (Table 1). For Fe-saponite found in DSDP Leg 81 tholeiites (Desprairies et al., 1984 and unpublished data) and having the same chemical composition, this ratio can reach lower values $(0.15$ to 0.35$)$, decreasing from the central part toward the top of each flow.

Trioctahedral smectites replacing pumices in the ignimbrite are mostly Fe-saponite. They differ from specimens described above by a higher $\mathrm{Al}_{2} \mathrm{O}_{3}$ percentage (Figs. 3 and 4) which may reflect the chemical composition of parental sources, i.e., tholeiites vs. trachy-basalt. 
Table 3. Averaged chemical analyses, structural formulas, and b-parameter of clay minerals from altered volcanic flows and volcaniclastic sediments of the lower series, Hole 642E. Samples 1, 2, 3: 104-642E-97R-1, 93-95 cm; -97R-2, 89-91 cm; -98R-2, 45-47 cm; -98R-2, 88-90 cm; -98R-3, 82-84 cm; -99R-1, 10-15 cm. Samples 4, 5: 104-642E108R-1, 29-31 cm. Sample 1: Fresh glass; Sample 2: Beidellite from altered glass; Sample 3: Iron-rich beidellite infilling vesicles; Samples 4, 5: Saponite and mixture of saponite and beidellite from altered groundmass and pumices. Total iron is expressed as $\mathrm{FeO}$ or $\mathrm{Fe}_{2} \mathrm{O}_{3}$. ( $\mathrm{Nb}$ ) is number of averaged analyses.

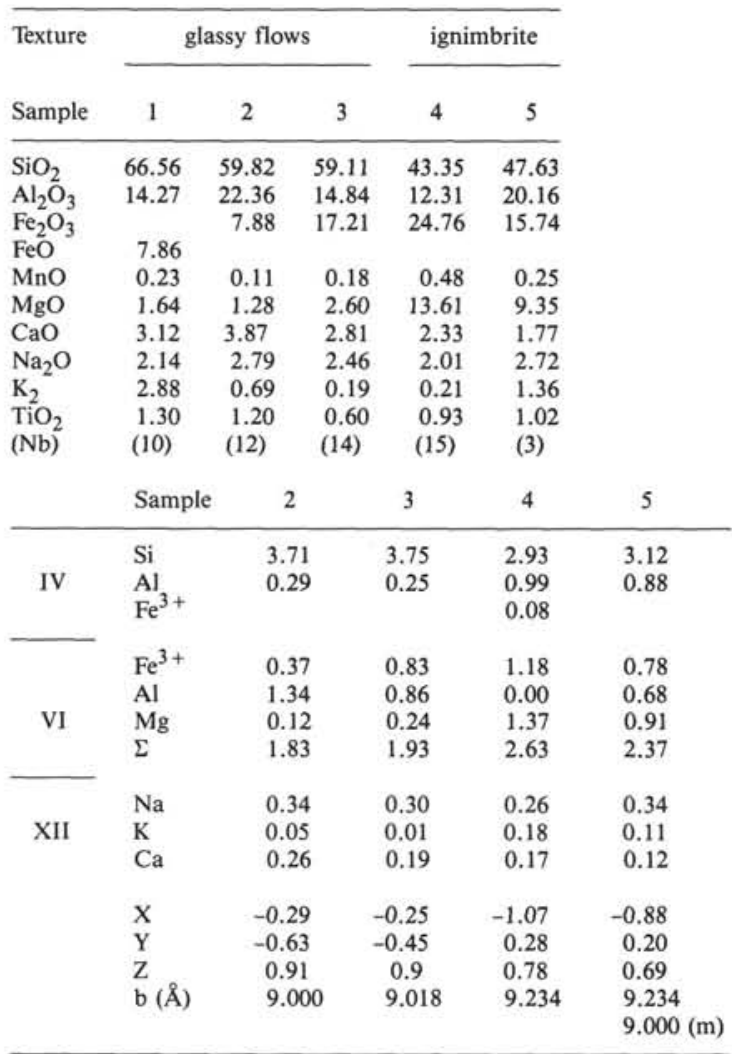

\section{Mg-Saponite}

Green to light-green in color, those occur mainly in the vesicular top and base of flows and always postdate the early filling of zoned vesicles and fractures with $\mathrm{Fe}$-saponite. $\mathrm{Mg}$-saponite is distinguishable not only by $\mathrm{MgO} /\left(\mathrm{Fe}_{2} \mathrm{O}_{3}+\mathrm{FeO}\right)$ ratios $>1$ but also by higher $\mathrm{FeO} / \mathrm{Fe}_{2} \mathrm{O}_{3}$ ratios ( 0.67 to 1.06 , Table 1$)$. As for $\mathrm{Fe}$-saponite, in Leg 81 tholeiites this type shows lower $\mathrm{FeO} /$ $\mathrm{Fe}_{2} \mathrm{O}_{3}$ values ( 0.86 to 0.34 ), especially at the upper part of the vesicular top of flows, just below volcaniclastic sediments. However, in each zoned vesicle or fracture from Leg 104 as well as from Leg 81 tholeiites, the $\mathrm{FeO} / \mathrm{Fe}_{2} \mathrm{O}_{3}$ ratio for $\mathrm{Fe}$-saponite is lower than that for adjacent $\mathrm{Mg}$-saponite. Furthermore, the Xray data (doublet of 06,33 band, unusual swelling) suggest that the Mg-smectites are a mixture of low-charge saponite and highcharge saponite or vermiculite.

\section{Beidellite-Nontronite Series}

Dioctahedral smectites with intermediate chemical composition between the end-members beidellite and nontronite are common in the alteration products from the upper and lower se-
Table 4. Chemical analyses and structural formulas for zeolites found with coexisting clay minerals in the upper and lower lavas series, Hole 642E. Sample 1: Glass replacement in brown vitric tuff with matrix of ironoxides and saponite. Samples 2 and 3: In dark-gray conglomeratic-to-brecciated top of basaltic flow, lining of vesicles and vugs infilled with saponite and celadonite. Sample 4: Within one ignimbrite flow, rim and cement of pumice clasts altered to a mixture of saponite and beidellite. $(\mathrm{Nb})$ is the number of averaged analyses. Number of ions on the basis of 32 (Phillipsite), $\mathbf{4 8}$ (Mordenite) and 72 (Chabazite) oxygens. $\mathbf{R}=(\mathbf{M g}+$ $\mathrm{Ca}+\mathrm{Na}+\mathbf{K})$

\begin{tabular}{|c|c|c|c|c|}
\hline \multirow{2}{*}{$\begin{array}{l}\text { Core 104-642E- } \\
\text { Section } \\
\text { Interval (cm) } \\
\text { Mineral } \\
\text { Sample }\end{array}$} & \multicolumn{2}{|c|}{$\begin{array}{c}85 R \\
5 \\
131-132 \\
\text { Chabazite }\end{array}$} & \multirow{2}{*}{$\begin{array}{c}\text { 19R } \\
5 \\
23-25 \\
\text { Phillipsite } \\
3\end{array}$} & \multirow{2}{*}{$\begin{array}{c}108 \mathrm{R} \\
1 \\
29-31 \\
\text { Mordenite } \\
\end{array}$} \\
\hline & 1 & 2 & & \\
\hline $\mathrm{SiO}_{2}$ & 48.81 & 49.34 & 54.08 & 63.67 \\
\hline $\mathrm{Al}_{2} \mathrm{O}_{3}$ & 20.95 & 19.87 & 18.60 & 10.97 \\
\hline $\mathrm{Fe}_{2} \mathrm{O}_{3}$ & 0.91 & - & 0.41 & 0.23 \\
\hline $\mathrm{MgO}^{2}$ & 0.12 & - & - & - \\
\hline $\mathrm{CaO}$ & 8.34 & 8.84 & 0.60 & 2.31 \\
\hline $\mathrm{Na}_{2} \mathrm{O}$ & 2.76 & 2.11 & 8.37 & 3.98 \\
\hline $\mathrm{K}_{2} \mathrm{O}$ & 2.82 & 0.58 & 4.78 & 0.31 \\
\hline$\Sigma$ & 84.71 & 75.34 & 86.84 & 81.48 \\
\hline$(\mathrm{Nb})$ & (3) & (1) & (1) & (3) \\
\hline $\mathrm{Si}$ & 23.54 & 23.44 & 11.30 & 19.91 \\
\hline $\mathrm{Al}$ & 11.89 & 12.51 & 4.57 & 4.02 \\
\hline $\mathrm{Fe}$ & 0.35 & - & 0.05 & 0.07 \\
\hline $\mathrm{Mg}$ & 0.09 & - & - & \\
\hline $\mathrm{Ca}$ & 4.32 & 5.07 & 0.14 & 0.77 \\
\hline $\mathrm{Na}$ & 2.55 & 2.18 & 3.39 & 2.40 \\
\hline K & 1.74 & 0.38 & 1.28 & 0.11 \\
\hline $\mathrm{R}$ & 8.70 & 7.63 & 4.81 & 3.28 \\
\hline
\end{tabular}

ries. Pure end-member beidellite is restricted to the lower series and pure nontronite was never detected.

\section{Beidellite}

Glassy flows of the lower series often exhibit white to lightgray coloration due to leaching by hydrothermal fluids. In such cases, beidellite is easily formed from silicic glass, mainly by loss of $\mathrm{Si}$ and $\mathrm{K}$ (Table 3). This latter element is not completely leached, and the characteristics of this beidellite are related to the chemical composition of the parental rock, potassium being the main interlayer cation with a small amount of $\mathrm{MgO}$. Iron beidellite, widespread in the brown matrix of breccia and vitric tuffs from the upper series, shows considerable iron content (Table 2). Continuous substitution of $\mathrm{Al}$ by $\mathrm{Fe}$ can be observed in the analyses. This mineral also replaces glass of red-brown tuffs but was never found in altered groundmass of tholeiitic flows. In the lower series, vesicles are often lined with this smectite. Iron-beidellite from the upper series contains potassium as the interlayer cation, which may be attributed to the composition of the tuffs. On the other hand, their MgO-content (Fig. 3) is higher than that of iron-beidellites from the lower series (Fig. 4) and is clearly related to the parental rock.

\section{Celadonite}

This mineral was found only in the upper series. Its formation always follows that of Fe-saponite and its crystallization occurs either before, or concurrently with Mg-saponite. Celadonite from volcaniclastic sediments is more aluminous than that from flows. In contrast to saponite, celadonites do not show tetrahedral cation deficiency and their range of $\mathrm{MgO}$ / $\left(\mathrm{Fe}_{2} \mathrm{O}_{3}+\mathrm{FeO}\right)$ ratios (Table 1$)$ are more restricted $(0.3$ to 0.4$)$. The $\mathrm{FeO} / \mathrm{Fe}_{2} \mathrm{O}_{3}$ ratio can be low, as for Fe-saponite $(0.18)$ and 


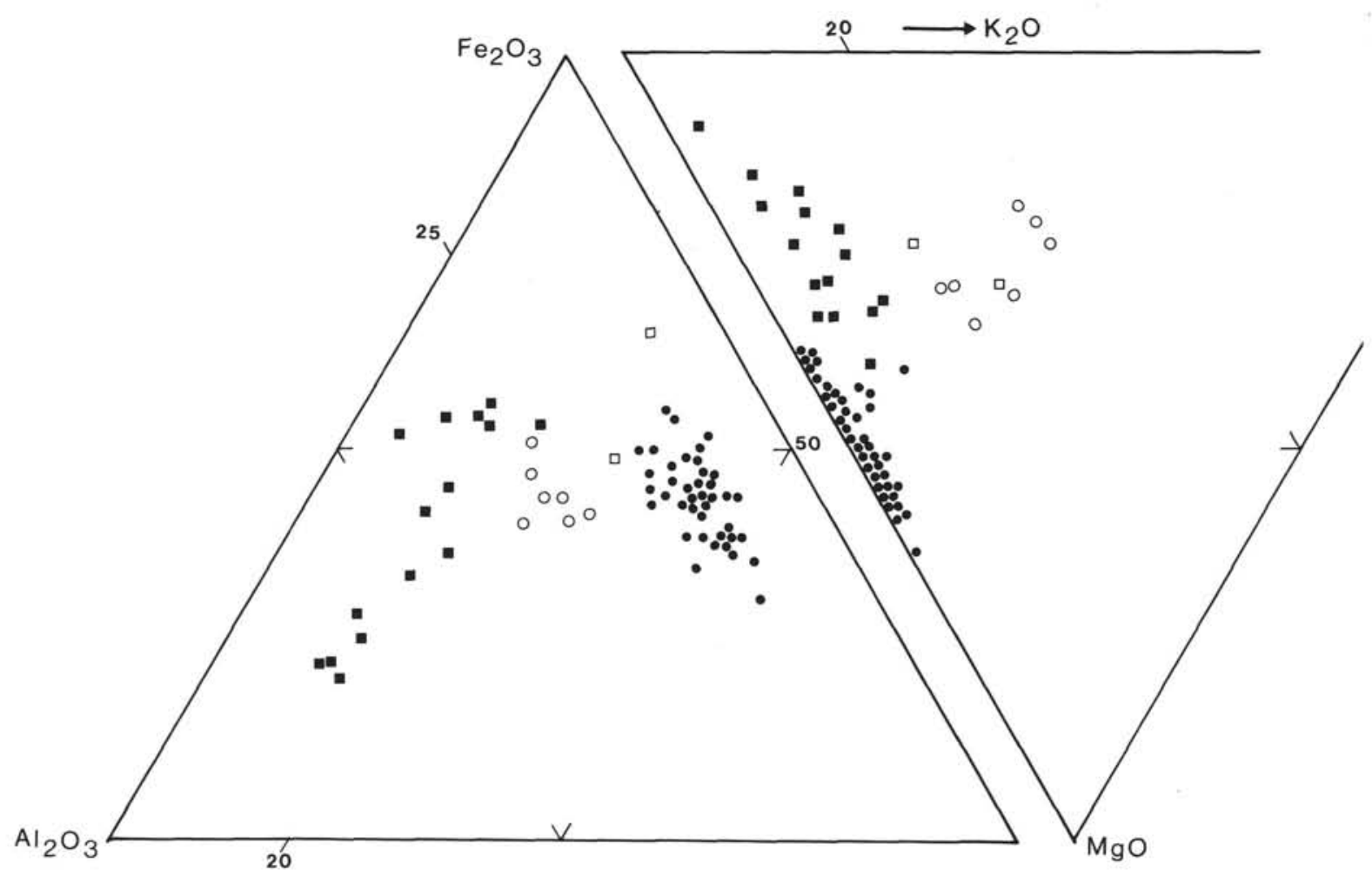

Figure 3. $\mathrm{Fe}_{2} \mathrm{O}_{3}-\mathrm{Al}_{2} \mathrm{O}_{3}-\mathrm{MgO}$ and $\mathrm{MgO}-\mathrm{Fe}_{2} \mathrm{O}_{3}-\mathrm{K}_{2} \mathrm{O}$ (oxides) ternary diagrams presenting the chemical composition of secondary clay minerals found in the upper volcanic series, Hole $642 \mathrm{E}$ basaltic flows: filled circles, saponite; open squares, celadonite volcaniclastic sediments; filled squares, beidellite; open circles, celadonite.

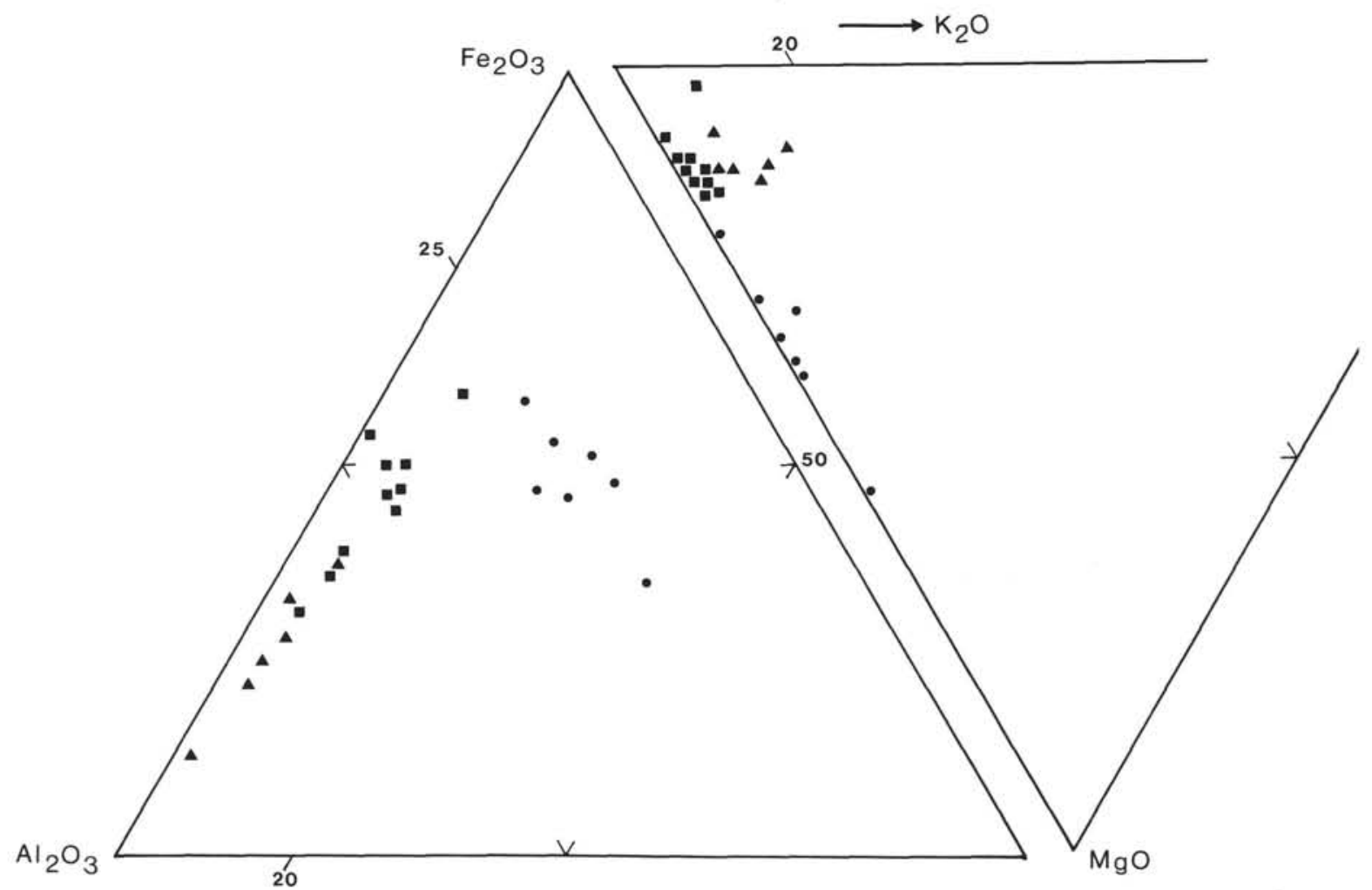

Figure 4. $\mathrm{Fe}_{2} \mathrm{O}_{3}-\mathrm{Al}_{2} \mathrm{O}_{3}-\mathrm{MgO}$ and $\mathrm{MgO}-\mathrm{Fe}_{2} \mathrm{O}_{3}-\mathrm{K}_{2} \mathrm{O}$ (oxides) ternary diagrams showing the chemical compositon of authigenic clay minerals found in the lower volcanic series, Hole 642E. Filled circles, saponite; filled squares iron-rich beidellite; filled triangles, beidellite. 
depends strictly on the location of the sample within each volcanic flow. However, Mössbauer studies on Leg 81 samples (Decarreau and Desprairies, in prep.) indicate that within a given vesicle or fracture, celadonite always exhibits higher $\mathrm{FeO} / \mathrm{Fe}_{2} \mathrm{O}_{3}$ ratios than $\mathrm{Mg}$-saponite.

\section{Isotopic Studies}

Samples were selected in the upper series from zoned fracture and vesicle fillings of saponite and celadonite. Furthermore, the samples are from different internal structural horizons within flows (Table 5).

\section{Celadonite}

$\delta^{18} \mathrm{O}$ values range from $19.7 \%$ to $17.4 \% 0$ assuming crystallization from water with $\delta^{18} \mathrm{O}=0 \%$. Using the glauconite-water fractionation factor of Savin and Epstein (1970), we arrive at temperatures of $35^{\circ}-50^{\circ} \mathrm{C}$ for celadonite formation. These temperatures are maximum values, and any negative shift of the $\delta^{18} \mathrm{O}$ of $\mathrm{H}_{2} \mathrm{O}$, as observed during low-temperature $\left(<200^{\circ} \mathrm{C}\right)$ seawater-basalt interaction (Lawrence et al., 1975), will decrease the apparent temperature. Previously documented data for oceanic celadonites, associated with nontronite and quartz-calcite assemblages of latest precipitation stage, are very similar (Kastner and Gieskes, 1976; Seyfried et al., 1978; Stakes and O'Neil, 1982; Bölke et al., 1984). However, for Leg 81 tholeiites from Rockall Plateau, extruded in an environment comparable to Vøring Plateau, lower $\delta^{18} \mathrm{O}$ values $(17.1 \%$ to $13.4 \%$ ) were found for celadonite associated with saponite (Table 6). Assuming the same parameters, calculated temperatures range from $50^{\circ}$ to $85^{\circ} \mathrm{C}$.

\section{Saponite}

The estimated saponite formation temperatures are between $70^{\circ}$ and $130^{\circ} \mathrm{C}$, based on $\delta^{18} \mathrm{O}$ values of $22.8 \% 0$ to $17 \% 0$ and using the trioctahedral $\mathrm{Mg}$-smectite-water fractionation curve of Escande (1983). Calculations using the dioctahedral Al-Fesmectite-water fractionation curve of Yeh and Savin (1977) give much lower temperatures $\left(38^{\circ}\right.$ to $\left.76^{\circ} \mathrm{C}\right)$, which contradicts the frequent intergrowth of saponite-celadonite (Figs. 3 to 4). In altered oceanic rocks, saponite formation can occur over a large temperature range up to $170^{\circ}-200^{\circ} \mathrm{C}$ (Stakes and O'Neil, 1982). On the other hand, Leg 104 data are consistent with those for Leg 81 samples (Table 6) where temperatures of $65^{\circ}$ to $115^{\circ} \mathrm{C}$ were deduced from isotopic values $(23.6 \%$ to $18.5 \%$ ). In one sample with zoned or intergrowth vesicle-filling of saponite and celadonite, estimated temperatures are very similar for both minerals. In Leg 81 tholeiites, temperature gradients inferred for both minerals appear to be linked to the internal structure of each flow and decrease from the central part toward the vesicular top (Table 6). Such a trend is stated assuming constant fluid composition under conditions of high water-to-rock ratio. Another intepretation is that progressive seawater reaction with the rocks at low temperature $\left(<200^{\circ} \mathrm{C}\right)$ led to $\delta^{18} \mathrm{O}$ depletion with depth in the fluid. In that case, under conditions of more restricted fluid circulation toward the central part of each basaltic flow, the same distribution of $\delta^{18} \mathrm{O}$ values could be obtained at constant temperature. At Hole $642 \mathrm{E}$, considering the small amount of isotopic data, a gradient within each flow cannot be demonstrated. However, the decrease of saponite isotopic values with increasing depth, independent of the internal flow structure, suggests a global increase of the heat and/or change in fluid composition toward the base of the upper series.

\section{DISCUSSION}

\section{Spatial Distribution}

The occurrence of clay minerals in the upper volcanic series is related to zonal distributions within each flow unit.

\section{Volcaniclastic Sediments and Upper \\ Brecciated-to-Conglomeratic Zone}

A common characteristic of these sediments is the red color grading progressively to green at the contact with the underlying vesicular zone. This color change is particularly obvious for the glassy component of tuffs at the top of this zone, which are completely transformed into a mixture of goethite-hematite-iron beidellite, associated in some cases with kaolinite and/or halloysite, but replaced at the base by an iron beidellite-saponite assemblage. The same mineralogical evolution arises for brecciated basalt elements which range from the entire alteration of interstitial glass and pyroxene-olivine and plagioclases phenocrysts into oxides-clays assemblages, to partial alteration restricted to the matrix. It is important to note that the interstices between basaltic fragments, reddened or not, are frequently filled with a saponite-celadonite assemblage identical to that found in the underlying zone.

\section{Upper Vesicular Zone}

The basaltic groundmass in vesicular flow tops is completely altered to Fe-rich saponite. The crystallization sequence in vesicle or fracture fillings is always the same; proceeding from rim to core, this sequence consists of a thin line of massive Fe-rich saponite, dark-green to black in color, followed by bluish green celadonite, light-green fibrous $\mathrm{Mg}$-rich, Fe-poor saponite, and finally calcite. Frequent intergrowth of celadonite-Mg-saponite was also observed (Fig. 5). At the most external highly vesicular part of this zone, often exhibiting purplish reddish coloration, the typical alteration sequence does not include $\mathrm{Mg}$-saponite. In this latter case $\mathrm{Fe}$-saponite, mixed with various amounts of iron-beidellite, is followed by a mixture of celadonite, some-

Table 5. Oxygen isotope data for clay minerals extracted from vesicles of the upper volcanic series, Hole $642 \mathrm{E}$. Temperature calculated by assuming formation in equilibrium with water at $0 \%$ and using the fractionation factor of glauconite (Savin and Epstein, 1970) for celadonite, and of Mg-smectites (Escande, 1983) for saponite. The chemical analyses of samples are given in Tables 1 and 2.

\begin{tabular}{llccl}
\hline $\begin{array}{c}\text { Sample } \\
104-642 \mathrm{E}-\end{array}$ & Mineral & $\begin{array}{c}\delta^{18} \mathrm{O} \% 0 \\
(\mathrm{SMOW})\end{array}$ & $\begin{array}{c}\text { Calculated } \\
\text { temperature } \\
\left(\mathrm{C}^{\circ}\right)\end{array}$ & \multicolumn{1}{c}{ Comments } \\
\hline $14 \mathrm{R}-1,97-98 \mathrm{~cm}$ & Celadonite & 19.70 & 35 & brecciated top of flow \\
$33 \mathrm{R}-3,87-88 \mathrm{~cm}$ & Celadonite & 17.40 & 50 & vesicular top \\
& Saponite & 22.80 & 72 & central streaky zone \\
$22 \mathrm{R}-4,129-132 \mathrm{~cm}$ & Saponite & 19.71 & 100 & upper vesicular zone \\
$47 \mathrm{R}-1,15-16 \mathrm{~cm}$ & Saponite & 19.22 & 105 & \\
$63 \mathrm{R}-1,66-68 \mathrm{~cm}$ & Saponite & 17.04 & 130 & \\
\hline
\end{tabular}


Table 6. Oxygen isotope data for the saponite-celadonite assemblage, DSDP Leg 81, Site 553. Temperature estimated using, as for Leg 104 minerals, fractionation factor of glauconite (Savin and Epstein, 1970), Mg-smectite (Escande, 1983) and quartzwater (Clayton et al., 1972).

\begin{tabular}{clccl}
\hline $\begin{array}{c}\text { Sample } \\
81-553 \mathrm{~A}-\end{array}$ & Mineral & $\begin{array}{c}\delta^{18} \mathrm{O} \% \\
(\mathrm{SMOW})\end{array}$ & $\begin{array}{c}\text { Calculated } \\
\text { temperature } \\
\left(\mathrm{C}^{\circ}\right)\end{array}$ & \multicolumn{1}{c}{ Location within flow } \\
\hline $40-1,40-42 \mathrm{~cm}$ & Quartz & 28.5 & 50 & $\begin{array}{l}\text { Massive chert with celadonite } \\
\text { filling vesicle-scoriaceous top }\end{array}$ \\
$39-2,38-40 \mathrm{~cm}$ & Celadonite & 17.1 & 50 & \\
$40-1,15-18 \mathrm{~cm}$ & Saponite & 23.6 & 65 & Zoned vesicles filling- \\
& Celadonite & 16.2 & 60 & Top part \\
$47-1,33-35 \mathrm{~cm}$ & Saponite & 21.3 & 85 & Zoned fracture filling-upper \\
& Celadonite & 14.6 & 70 & external part \\
$41-3,3-6 \mathrm{~cm}$ & Saponite & 20.9 & 90 & Zoned vesicle filling-medium \\
$58-2,34-36 \mathrm{~cm}$ & Celadonite & 13.4 & 85 & part \\
& Saponite & 18.5 & 115 & Fracture filling-medium part \\
\hline
\end{tabular}

times intergrowing with beidellite, and calcite. Finally, at the center of this zone, intermediate celadonite gradually disappears and the crystallization order is directly from $\mathrm{Fe}$-saponite to $\mathrm{Mg}$-saponite.

\section{Central "streaky" Zone}

Fissures and fractures in this zone are filled only with black, Fe-rich, Mg-poor saponite and, in several specimens, quartz is the final product. The basaltic groundmass remains unaltered.

\section{Lower Vesicular Zone}

The crystallization sequence evolves in the same way as for the upper vesicular zone, with progressive development toward the flow base of $\mathrm{Mg}$-saponite followed by celadonite.

An identical zonal distribution of alteration products, clearly related to their location within each flow unit, was observed throughout the entire tholeiitic section drilled during DSDP Leg 81 on the Rockall Plateau (Roberts, Schnitker, et al., 1984; Desprairies et al. 1984).

In the lower volcanic series of Hole 642E, alteration of glass and pumice into beidellite or iron-saponite-beidellite assemblages is pervasive, and no zonal distribution of clay minerals within each individual flow is recognized. In the sequential filling of vesicles, celadonite is always absent; iron-beidellite is usually the first crystallized mineral, followed by zeolites.

\section{Temporal Evolution}

Various studies have shown that the ageing of oceanic crust at low temperature results in successive alteration stages (e.g., Honnorez, 1981 and references therein).

According to most authors, celadonite formation in vesicles and cracks occurs under oxidizing conditions; however, opinions differ on the timing, nature, and origin of circulating fluids which generate $\mathrm{Mg}$ precipitation. Basalt-seawater interaction (halmyrolysis) can take place during a preburial phase of diagenesis, immediately after the basalt extrusion (Andrews, 1980) or after a first stage of formation of palagonite (Staudigel et al., 1981). Postburial alteration can occur after the burial by younger lavas or sediments (Bass, 1976). Mixing of hydrothermal fluids with oxygenated seawater (Alt and Honnorez, 1984) or reaction of the cooling basalt with seawater (Humphris et al., 1980) are also possible processes of celadonite formation occurring during an early stage.

The position of smectites relative to celadonite in sequential filling of fractures and vesicles reflects oxidizing and/or nonoxidizing conditions prevailing during preburial and/or postburial stages. Usually, Fe-rich saponite and nontronite are reported to be characteristic of nonoxidizing diagenesis before or after celadonite forms (Scheidegger and Stakes, 1977; Seyfried et al., 1978; Andrews, 1980; Alt et al., 1986) and Mg-saponite, with celadonite, as characteristic of oxidizing diagenesis. However, opinions often differ from author to author on the strict definition of $\mathrm{Mg}$-saponite vs. Fe-saponite, and in the redox conditions inferred by $\mathrm{Fe}^{2+} / \mathrm{Fe}^{3+}$ ratios for the same minerals.

In Hole 642E, subaerial weathering of ferruginous volcaniclastic sediments from the upper series is marked both by the presence of rounded, reworked clasts and clay minerals (halloysite, kaolinite) characteristic of soils. Voids and interstices between epiclastic fragments are filled with a celadonite-Mg-smectite and/or calcite assemblage obviously generated after the former stage of alteration.

In tholeiitic flows, celadonite and associated minerals postdate Fe-saponite, which always constitutes the first-formed mineral in the sequential filling of vesicles or cracks and, in reddened breccia, follows the mixture of Fe-saponite-iron-beidellite lining the amygdule rims. Identical Fe-saponite is found in the altered groundmass, grading to iron-beidellite in a parallel evolution with that of the first smectite-infilling vesicles. From these observations, we suggest four superimposed stages of alteration in the upper series:

1. The first stage occurs at the time of basalt extrusion. Seawater-volcanic material interaction develops $\mathrm{K}$-rich iron-beidellite in tuffs (hyaloclastites) following a process similar to palagonitization (Honnorez, 1981). Simultaneously, seawater penetrates into the volcanic flow. Reaction with basalt under high water-rock ratio and less oxidizing conditions induces Fe-saponite formation, with low $\mathrm{Fe}^{2+} / \mathrm{Fe}^{3+}$ ratio. There is sometimes association with iron-beidellite at the vesicular top. Continuous extraction of oxygen from inflowing seawater results in the progressive development of $\mathrm{Fe}$-saponite showing high $\mathrm{Fe}^{2+} / \mathrm{Fe}^{3+}$ ratio toward the central part of flows. This evolution with depth from oxidizing to reducing environments is expressed by a change in color of the smectites from brownish to black, which may be observed in altered groundmass as well as in filled vesicles.

2 . The second stage, subaerial weathering, was not clearly defined in the alteration sequence of Leg 81 basalts (Desprairies et al., 1984). The good recovery of volcaniclastic sediments during Leg 104 permits the inferrence that this stage takes place, intermittently, between two emissions of flows in a very shallow to subaerial environment (Eldholm, Thiede, Taylor, et al., 1987). In this context, we assume that soil clay minerals partially develop at the expense of smectites previously formed during the first stage. Consequently, it is likely that a part of the Fe-Sapo- 

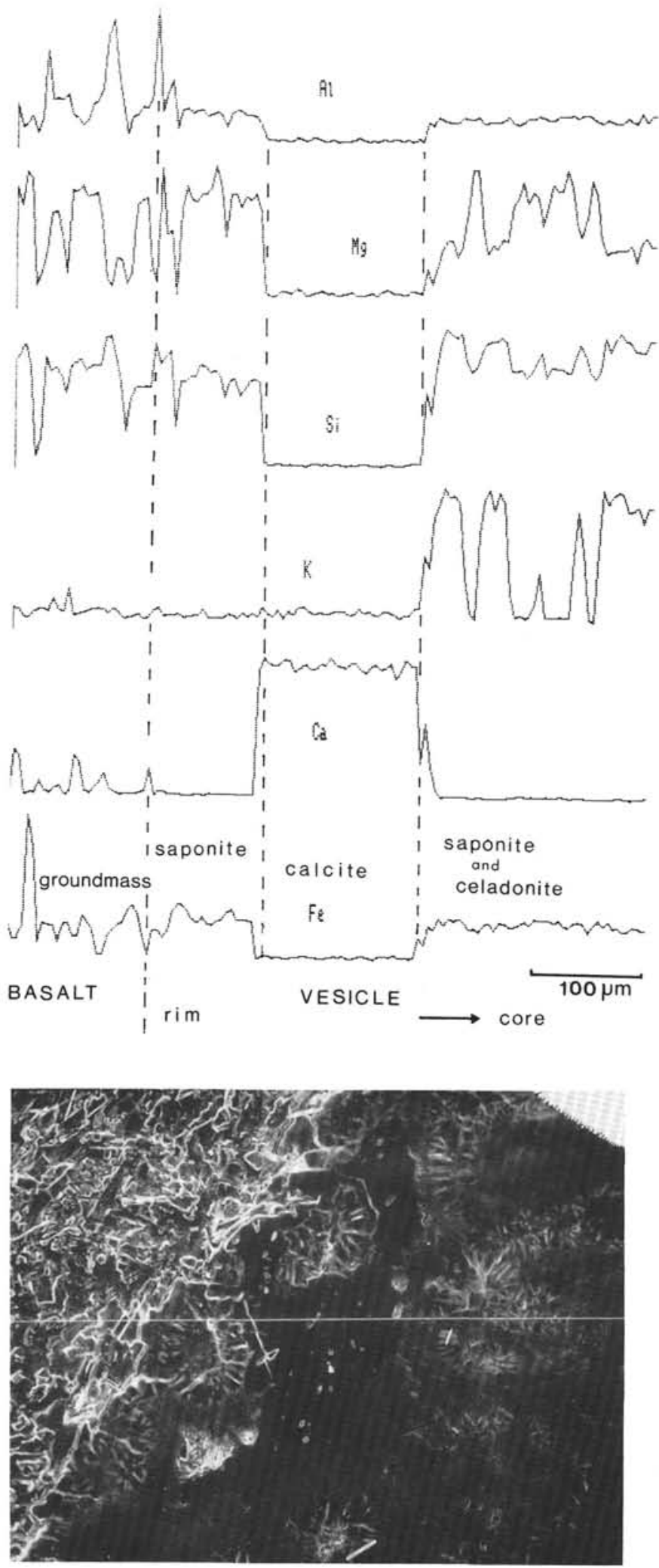

Figure 5. Sample 104-642E-16R-3, 114-116 cm SEM/EDS analysis. Line profile of major elements relative concentration across a vesicle containing, from rim to core, saponite, calcite, and saponite-celadonite intergrowth. Note the opposite trend for $\mathrm{Si}-\mathrm{K}$ relative to $\mathrm{Mg}$ and the flat distribution of $\mathrm{Al}$ and $\mathrm{Fe}$. nite formed under reducing conditions, has been subsequently oxidized during this second stage.

3. The third stage, affecting both rocks and sediments, coincides with the $\mathrm{Mg}$-saponite-celadonite assemblage and, on the basis of chemical and isotopic analyses, is considered as being hydrothermal. The relationship between celadonite and smectites is an important point and is discussed below.

4. The fourth stage, observed during shipboard analyses, is characterized in the lower part of the tholeiitic column by a leaching around the higher porosity zones (fractures, vesicles). It is widely developed throughout the lower series; the mineral assemblage related to this late, pervasive alteration is distinguished by $\mathrm{Al}$-smectite-zeolites-siderite-quartz sequence of crystallization. The presence of sulfides and the dominant Al-rich, $\mathrm{Mg}$-poor composition of minerals suggest Mg-depleted, alkaline and reduced, hydrothermal fluids (Alt et al., 1986).

\section{Formation Conditions of the Smectites-Celadonite Assemblage}

According to several authors, and as mentioned above, changes in local fluid environments and, especially, the oxidation states, control celadonite formation. Some authors propose direct precipitation (Bass, 1976; Scheidegger and Stakes, 1977; Humphris et al., 1979) while others suggest saponite as a precursor (Seyfried et al., 1976; Scheidegger and Stakes, 1979; Windom and Book, 1981). Andrews (1980) explains the mineralogical sequence $\mathrm{Fe}^{3+}$-oxide-celadonite-saponite, proceeding outward from a vein, by a "gradual and systematic extraction of oxygen from the inflowing seawater during progressive reaction with the massive crystalline basalt." During this process, $\mathrm{Fe}^{3+}$ oxide replaces previously formed celadonite which in turn replaces previously formed saponite along sharp fronts separating each zone. According to the author, the replacement process is reflected by interlayering of saponite in celadonite; $\mathrm{Si}, \mathrm{Al}$, and $\mathrm{Mg}$ in goethite represent remnants of original phyllosilicate minerals. In turn, saponite compositions are very close to the stoichiometric ideal, and their generation does not involve a replacement process.

In Leg 104 samples we did not find celadonite indexes of interlayering with Mg-saponite, although TEM observations and elemental mapping (Fig. 6) indicate an intimate mixture of these two minerals. Preliminary Mössbauer investigations of Leg 81 samples also show that the spectra and iron site occupancy of the two minerals are quite different. Celadonites are characterized by $\mathrm{Fe}^{3+}$ ions located only in $\mathrm{M} 2$ sites and $\mathrm{Fe}^{2+}$ ions distributed in both $\mathrm{Ml}$ and M2 sites. In saponites, $\mathrm{Fe}^{2+}$ ions are located in $\mathrm{M} 2$ sites and $\mathrm{Fe}^{3+}$ ions distributed in both M2 and M1 sites. The atomic ratio $\mathrm{Fe}^{2+}\left(\mathrm{Fe}^{2+}+\mathrm{Fe}^{3+}\right)$ of all Leg 81 samples is higher in the celadonite than in the coexisting $\mathrm{Mg}$-saponite. $\mathrm{A}$ conversion or transformation of saponite into celadonite by a progressive interlayering involves complex, unrealistic, changes in sites of iron occupancy such as a transition of $\mathrm{Fe}^{3+}$ ions from the M1 to M2 site, accompanied by a partial in-situ reduction of these iron atoms. Conversion of saponite to celadonite at least implies a dissolution-reprecipitation mechanism. Another possible genetic hypothesis concerns coprecipitation of the two minerals. Such a process can be inferred, in part from previous studies on Leg 81 samples, as follows:

1. Estimated crystallization temperatures for Mg-saponite and celadonite are identical within the same vesicle or fracture filling and decrease gradually and concurrently outward from the central part of flows (Tables 5 and 6).

2. Rare-earth element distribution curves exhibit similar patterns with, in particular, the presence or absence in both miner- 

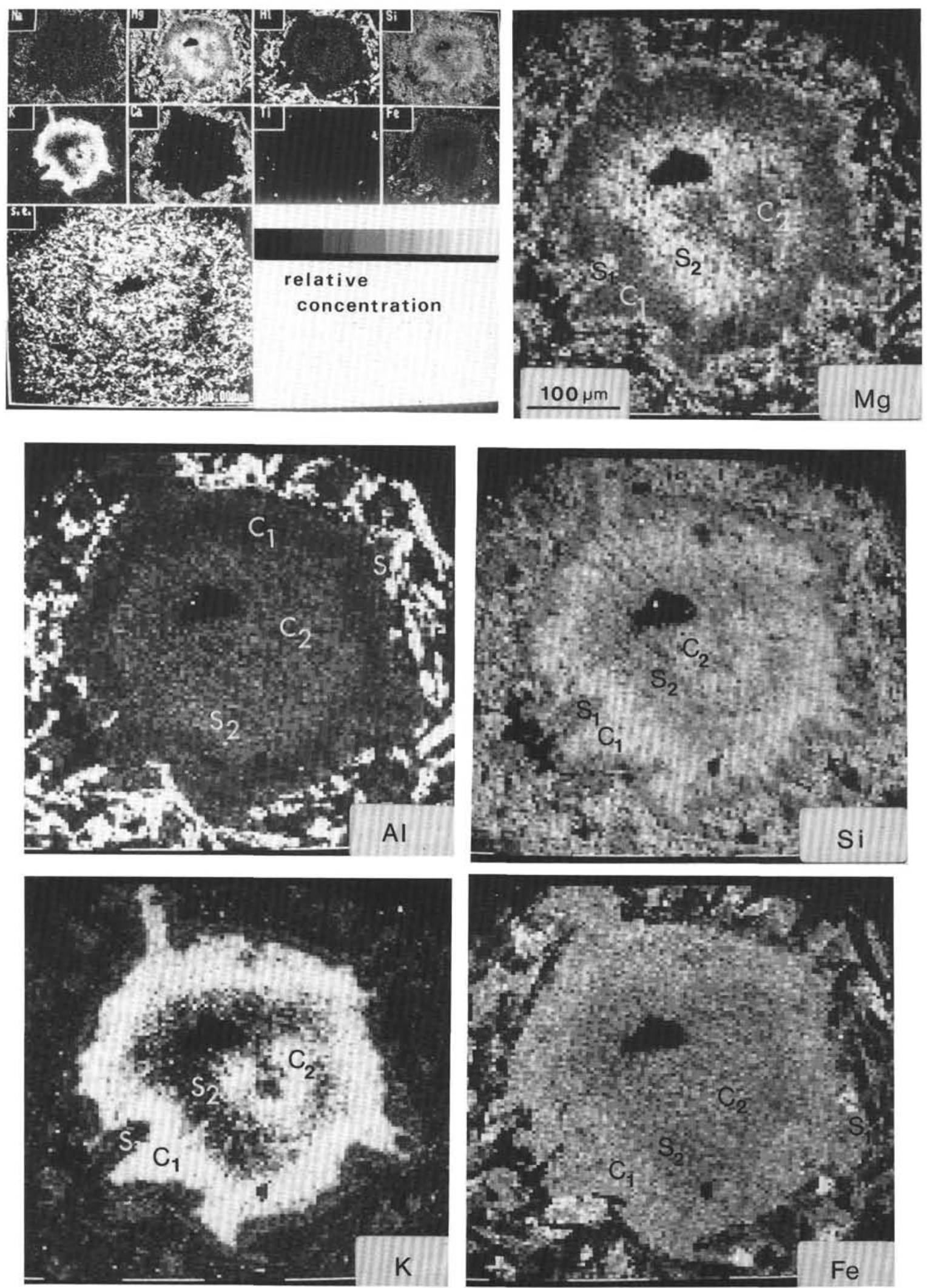

Figure 6. Sample 104-642E-33R-2, 47-49 cm SEM/EDS elemental mapping (Link System Digimap) of saponite-celadonite assemblage. From rim to core of filled vesicle, Mg-poor, Fe-rich saponite (S1), celadonite (C1), Mg-rich, Fe-poor saponite (S2) and celadonite (C2). The maps were defined on a matrix of $128 \times 128$ pixels with 8 or 16 bits/pixel. The time of acquisition was in all cases $400 \mathrm{~ms} /$ pixel and $51 \mu \mathrm{s}$ for secondary electrons. The brightnesses of the images presented are proportional to the apparent concentration of the element with a maximum of 16 levels of gray. 
als of positive or negative $\mathrm{Ce}$ anomalies (Desprairies et al., 1984). These patterns suggest a uniform chemical environment during crystallization of the two phyllosilicates and, eventually, similar redox conditions.

The majority of authors consider that oxidizing conditions prevail during celadonite formation. However, these conditions are relative and should be considered with respect to the precise location of samples. Flow-top $\mathrm{Fe}^{2+} / \mathrm{Fe}^{3+}$ ratios for celadonite are higher than those of adjacent saponites. With depth, these ratios do not change markedly and always remain higher than those of Mg-saponite but progressively become lower than those of Fe-saponite. Interpretation of oxidation-reduction conditions by $\mathrm{Fe}^{2+} / \mathrm{Fe}^{3+}$ ratio is critical. Initially, according to data reported by Kohyama et al. (1973) and Andrews et al. (1983), oxidation of $\mathrm{Fe}^{2+}$ to $\mathrm{Fe}^{3+}$ can occur quickly after core recovery under ambient laboratory conditions. In this context, values of $\mathrm{Fe}^{2+} / \mathrm{Fe}^{3+}$ ratios would not indicate original in-situ oxidation states. Nevertheless, relative values of $\mathrm{Mg}$-saponite remain significant. Subsequently, as already noted, subaerial weathering superimposed on submarine alteration can induce secondary oxidation of previous $\mathrm{Fe}$-saponite. Finally, in the same environment, potential redox for celadonite formation can be quite different from that of saponite and, as mentioned by Bass (1976), oxidized and reduced celadonite can occur during a nonoxidizing diagenetic stage.

In summary, the celadonite-Mg-saponite assemblage from the upper series is interpreted as a paragenesis of minerals characteristic, on the basis of paleotemperatures, of a hydrothermal stage clearly distinct from a previous basalt-seawater interaction (sea floor weathering) reflected by the dioctahedral Fe-smectite development. Within this assemblage, $\mathrm{Mg}$-saponite is the first precipitate but may also constitute the final fracture filling following $\mathrm{Fe}$-saponite. With the continuous extraction of $\mathrm{Mg}$, celadonite coprecipitates with $\mathrm{Mg}$-saponite and finally coexists alone with calcite. No drastic chemical environmental changes appear necessary to explain cogenetic phases without interlayering. Nevertheless, with respect to the late-reducing hydrothermal stage that occurred in the lower series, the celadonite-Mg-saponite assemblage indicates more oxidizing, alkaline conditions. An unresolved question concerns the origin of fluids, either normal seawater heated as the result of continuous emission of flows, or high-temperature K-enriched seawater recycled after a deeper magnesium extraction by earlier rock-solution exchange. The second process, well documented on mid-oceanic ridges, is less plausible for Leg 104 basaltic pile for two reasons:

1. Subaerial weathering alternates with submarine alteration. It is difficult to consider upwelling hydrothermal fluids throughout interbedded volcanic flows and soils developed on volcaniclastic sediments.

2. In the same environment, trace-element concentrations in Leg 81 saponite-celadonite assemblage are directely inherited (Desprairies et al., 1984) from fluid-tholeiites interaction.

\section{ACKNOWLEDGMENTS}

We wish to thank J. C. Alt and J. Thiede for offering many helpful suggestions and critical comments. We are also grateful to E. Taylor for editorially reviewing the manuscript. This study was supported by ASP ODP France.

\section{REFERENCES}

Alt, J. C., and Honnorez, J., 1984. Alteration of the upper oceanic crust, DSDP Site 417: mineralogy and chemistry. Contrib. Mineral. Petrol., 87:149-169.

Alt, J. C., Honnorez, J., Laverne, C., and Emmermann, R., 1986. Hydrothermal alteration of a $1 \mathrm{~km}$ section through the upper oceanic crust, Deep Sea Drilling Project Hole 504B: mineralogy, chemistry and evolution of seawater-basalt interactions. J. Geophys. Res., 91: 10309-10335.

Andrews, A. J., 1980. Saponite and celadonite in Layer 2 Basalts, DSDP Leg 37. Contrib. Mineral. Petrol., 73:323-340.

Andrews, A. J., Dollase, W. A., and Fleet, M. E., 1983. A Mössbauer study of saponite in Layer 2 basalt, Deep Sea Drilling Project Leg 69. In Cann, J. R., Langseth, M. G., et al. (Eds.), Init. Repts. DSDP, 69: Washington (U.S. Govt. Printing Office), 585-588.

Bass, M. N., 1976. Secondary minerals in oceanic basalts, with special reference to Leg 34, DSDP. In Yeats, R. S., Hart, S. R., et al., Init. Repts. DSDP, 34: Washington (U.S. Govt. Printing Office), 393432.

Böhlke, J. K., Alt, J. C., and Muehlenbachs, K., 1984. Oxygen isotopewater relations in altered deep sea basalts: low temperature mineralogical controls. Can. J. Earth Sci., 21:67-77.

Brindley, G. W., and Brown, G., 1980. Crystal structures of clay minerals and their X-ray identification. London (Mineralogical Society).

Clayton, R. N., and Mayeda, T. K., 1963. The use of bromine pentafluoride in the extraction of oxygen from oxides and silicates for isotopic analyses. Geochim. Cosmochim. Acta., 27:43-52.

Clayton, R. N., O'Neil, J. R., and Mayeda, T. K., 1972. Oxygen isotope exchange between quartz and water. J. Geophys. Res., 77:30573067.

Desprairies, A., Bonnot-Courtois, C., Jehanno, C., Vernhet, S., and Joron, J. L., 1984. Mineralogy and geochemistry of alteration products in Leg 81 basalts. In Roberts, D. G., Schnitker, D., et al., Init. Repts. DSDP, 81: Washington (U.S. Govt. Printing Office, 733-741.

Eldholm, O., Thiede, J., Taylor, E., et al., 1987. Proc. ODP, Init. Repts., 104: College Station, TX (Ocean Drilling Program).

Escande, M. A., 1983. Echangeabilité et fractionnement isotopique de l'oxygène des smectites magnésiennes de synthèse. Etablissement d'un géothermomètre [Ph. D. Thesis]. Paris XI University, Orsay, France.

Honnorez, J., 1981. The aging of the oceanic crust at low temperature. In Emiliani, C., Ed., The Sea, Vol. 7, The Oceanic Lithosphere: New York (John Wiley \& Sons), 525-587.

Humphris, S. E., Thompson, R. N., and Marriner, G. F., 1979. The mineralogy and geochemistry of basalt weathering, Holes 417A and 418A. In Donnelly, T., Francheteau, J., Bryan, W., Robinson, P., Flower, M., Salisbury, M., et al., Init. Repts. DSDP, 51, 52, 53, Pt. 2: Washington (U.S. Govt. Printing Office, 1201-1217.

Humphris, S. E., Melson, W. G., and Thompson, R. N., 1980. Basalt weathering on the East Pacific rise and the Galapagos spreading center, Deep Sea Drilling Project Leg 54. In Rosendahl, B. R., Hekinian, R., et al., Init. Repts. DSDP, 54: Washington (U.S. Govt. Printing Office), 773-783.

Kastner, M., and Gieskes, J. M., 1976. Interstitial water profiles and sites of diagenetic reactions, Leg 35, DSDP, Bellingshausen abyssal Plain. Earth Planet. Sci. Lett., 33:11-20.

Kohyama, N., Shimoda, S., and Sudo, T., 1973. Iron-rich saponite (ferrous and ferric forms). Clays Clay Miner., 21:229-237.

Lawrence, J. R., Gieskes, J. M., and Broecker, W. S., 1975. Oxygen isotope and cation composition of DSDP pore waters and the alteration of Layer II basalts. Earth and Planet. Sci. Lett., 27:1-10.

Roberts, D. G., Schnitker, D., et al., 1984. Init. Repts, DSDP, 81: Washington (U.S. Govt. Printing Office).

Savin, S. M., and Epstein, S., 1970. The oxygen and hydrogen isotope geochemistry of clay minerals. Geochim. Cosmochim. Acta, 34:2542 .

Scheidegger, K. F., and Stakes, D. S., 1977. Mineralogy, chemistry and crystallization sequence of clay minerals in altered tholeiitic basalts from the Peru Trench. Earth Planet. Sci. Lett., 36:413-422.

Scheidegger, K. F., and Stakes, D. S., 1979. X-ray diffraction and chemical study of secondary minerals from Deep Sea Drilling Project leg 51 holes 417A and 417D. In Donnelly, T., Francheteau, J., Bryan, W., Robinson, P., Flower, M., Salisbury, M., et al., Init. Repts. DSDP, 51, 52, 53, Pt. 2: Washington (U.S. Govt. Printing Office, 1253-1263.

Seyfried, W. E., Shanks, W. C., and Bischoff, J. L., 1976. Alteration and vein formation in site 321 basalts. In Yeats, R. S., Hart, S. R., et al., Init. Repts. DSDP, 34: Washington (U.S. Govt. Printing Office), 385-392.

Seyfried, W. E., Shanks, W. C., III, and Diddle, W. E., 1978. Clay mineral formation in DSDP Leg 34 basalt. Earth Planet. Sci. Lett., 41: 265-276. 
Suquet, H., De La Calle, C., and Pezerat, H., 1975. Swelling and structural organization of saponite. Clays Clay Miner., 23:1-9.

Suquet, H., Iyama, I., Kodama, J. T., and Pezerat, H., 1977. Synthesis and swelling properties of saponites with increasing layer charge. Clays Clay Miner., 25:231-242.

Stakes, D. S., and O'Neil, J. R., 1982. Mineralogy and stable isotope geochemistry of hydrothermally altered oceanic rock. Earth Planet. Sci. Lett., 57:285-304.

Staudigel, H., Hart, S. R., and Richardson, S. H., 1981. Alteration of the oceanic crust: processes and timing. Earth Planet. Sci. Lett., 52: 311-327,
Windom, K. E., and Book, P., 1981. Vein minerals in basalt, Hole 462A, Leg 61 of the Deep Sea Drilling Project. In Larson, R. L., Schlanger, S. O., Init. Repts. DSDP, 61: Washington (U.S. Govt. Printing Office), 647-651.

Yeh, H. W., and Savin, S. M., 1977. Mechanism of burial metamorphism of argillaceous sediments: 3.0-isotope evidence. Geol. Soc. Am. Bull., 88:1321-1330.

Date of initial receipt: 23 June 1987

Date of acceptance: 12 April 1988

Ms 104B-142 